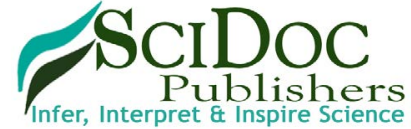

International Journal of Marine Science and Ocean Technology (IJMO)

ISSN: $2577-4395$

\title{
Wind Mitigating Action on Effects of Eutrophication in Coastal Eutrophic Water Bodies
}

Reserach Article

Lenzi $\mathrm{M}^{* 1}$, Persiano $\mathrm{M}^{1}$, Gennaro $\mathrm{P}^{2}$, Rubegni $\mathrm{F}^{3}$

${ }^{1}$ Lagoon Ecology and Aquaculture Laboratory (LEALab), via G. Leopardi 9, 58015 Orbetello, Italy.

${ }^{2}$ Institute for Environmental Protection and Research (ISPRA), via di Castel Romano 100/102, Pomezia 100-00128, Roma, Italy.

${ }^{3}$ Technical Department Civil Engineering and Marine Works, Tuscany Region, Corso Carducci 57, 58100 Grosseto, Italy.

\section{Abstract}

After a summer dystrophic event and a subsequent intense autumn bloom of cyanobacteria (chlorophyll $>31 \mu \mathrm{g} \mathrm{L}^{-1}$ ), the labile organic matter (LOM) in sediments of a Mediterranean lagoon, monitored for LOM, refractory organic matter, chlorophyll and anemographic data, increased by $113 \%$ after about 3 months (in December). In February, after two months in which the frequency of wind speeds exceeding $8 \mathrm{~m} \mathrm{~s}^{-1}$ averaged about 39\%, LOM declined by 39.1\% (two-way ANOVA, $\mathrm{P}=0.0012)$. Considering western (EL-W) and eastern (EL-E) halves of the eastern basin of the lagoon (EL), the former more exposed to strong prevailing winds in that period, we found that the former recorded a $65.5 \%$ reduction in LOM (significant $\mathrm{p}<0.01$ ), whereas the EL-E half recorded an increment of $5.1 \%$ (not significant, $\mathrm{p}>0.05$ ). LOM was not significantly different in the two halves in December, but differed significantly in February $(\mathrm{P}<0.01)$. These results sustain the role of wind in coastal lagoon environments, especially hypertrophic ones, and confirm the importance of resuspension of soft superficial sediments with high organic load in counteracting the effects of eutrophication.

Keywords: Eutrophication; Lagoon; Wind Energy; Sediment Organic Matter; Sediment Resuspension.

\section{Introduction}

Coastal areas are increasingly subject to eutrophic phenomena and their consequences [1]. These are largely due to increasing human coastal settlement and productive activities, as well as man-made material conveyed to the coast by rivers [2]. In the last ten years, there has also been a significant increase in temperature [3] that favours the already considerable primary production of phytoplankton [4] and opportunistic macroalgae [5].

As far as lagoons and especially coastal non-tidal lakes are concerned, the consequences of eutrophication and increased temperature are an increase in dystrophic phenomena, which consist in major sulphate-reducing events in the superficial layer of sediment, with release of hydrogen sulphide. Sulphatereducing activity is the major process by which organic matter is broken down in marine and transition environments [6]. This process can manifest as a change in water colour due to oxidation of hydrogen sulphide to colloidal sulphur in the water column.

In the last 15 years, our laboratory has studied the effects of sediment resuspension in non-tidal eutrophic water bodies in terms of consequences of eutrophication [7-9] and effects on sediment [10], vegetation [11] and the zoobenthos [12]. What we found was that resuspension tends to reduce the burden of organic matter in sediment, lowering sulphate-reducing activity and hence the risk of extended dystrophic processes [13, 14].

The aim of the present paper was to demonstrate the mitigating action of wind on water bodies with low water turnover, subject to eutrophication, and therefore to validate the importance of resuspension of sediment for prevention and control of eutrophication. Here we show that accumulation of organic matter produced by microphytic blooms was subsequently mitigated by a period with an unusually, high frequency of strong winds.

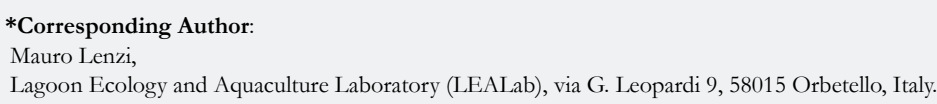

Citation: Lenzi M, Persiano M, Gennaro P, Rubegni F (2016) Wind Mitigating Action on Effects of Eutrophication in Coastal Eutrophic Water Bodies. Int J Marine Sci Ocean Technol. 3(2), 14-20. doi: http://dx.doi.org/10.19070/2577-4395-160004

Copyright: Lenzi $\mathbf{M}^{\circ}$ 2016. This is an open-access article distributed under the terms of the Creative Commons Attribution License, which permits unrestricted use, distribution and reproduction in any medium, provided the original author and source are credited. 


\section{Materials and Methods}

\section{Study area}

Orbetello lagoon is a shallow, non-tidal, eutrophic environment with low water-turnover on the Tyrrhenian coast $\left(42^{\circ} 25^{\prime}-\right.$ $\left.42^{\circ} 29^{\prime} \mathrm{N} ; 11^{\circ} 10^{\prime}-11^{\circ} 17^{\prime} \mathrm{E}\right)$. It consists of communicating western $\left(15.25 \mathrm{~km}^{2}\right)$ and eastern $\left(10.00 \mathrm{~km}^{2}\right)$ basins (Figure 1). The lagoon is substantially eutrophic due to fish farming, an intermittent stream containing agricultural run-off, and nutrient-rich sediment from wastewater discharged in the past [15].

In this study, we examine events that occurred in the following order in the eastern basin in the period July 2015 to March 2016: 1) prolonged intense dystrophy; 2) a microphytic bloom; 3) a sharp increase in organic matter in sediment throughout the basin; 4) a high frequency of days with strong winds; 5) a reduction in organic matter in the half of the basin most exposed to wind. To achieve the goal that we set ourselves we considered: 1) the quantity of labile organic matter in sediments since 2014; 2) estimates of the bloom occurring in the eastern basin between September 2015 and January 2016; 3) wind speeds and direction over the basin in the period October 2015-March 2016; 4) monthly temperatures compared with those of the previous two years.

\section{Conceptual models}

Non tidal coastal water bodies have little water exchange with the sea and tend to accumulate most of the material that enters them. This makes them vulnerable to eutrophication. Their eutrophic character increases if they receive industrial and urban effluent. One result is the development of opportunistic macroalgae and microphytes, followed by an increase in sediment organic matter content. Organic sedimentary deposits form a substrate for anoxygenic bacteria, especially in summer. Sulphate-reducing bacteria break down most of this organic matter, producing toxic hydrogen sulphide gas. Sulphate reduction may also occur diffusely and silently in sediment, in which case the organic matter is consumed slowly and the gas is released in small quantities and gradually oxidised at the bottom or in the bottom few millimetres or centimetres of the water column. When the process involves the whole water column it can lead to die off of most aquatic organisms, a phenomenon known as dystrophy: a vast dissipative process by which the ecosystem reduces accumulated energy. Dystrophic events depend on three main factors: the percentage of organic matter in sediments, water temperature and water turnover (Figure 2). The process creates an abundance of chemically reduced compounds in the water column and in sediments, which besides the direct toxicity of hydrogen sulphide, leads to hypoxia/anoxia for a relatively long period and a relatively acid condition of sediments.

Anoxygenic mineralisation of organic matter releases nutrient salts, including orthophosphates, which in an acid environment become soluble and bioavailable [16]. These drastic conditions are not yet suitable for the proliferation of macroalgae, but microphytes may develop on the basis of available nutrients. Through rapid turnover, microphytes acquire better tolerance to environmental stress.
After this dissipation of energy, sediments are freed of organic matter and environmental conditions become suitable for recolonisation by a greater number of plant and zoobenthic species. As the sediment is again gradually enriched with organic matter, the number of species falls and opportunistic ones tend to prevail, developing in large quantities. Release of nutrients by the sediment increases and changes from oxidised forms such as nitrates to reduced forms such as ammonium. Predystrophic conditions are gradually restored. The frequency of these events increases with increasing eutrophication of the ecosystem and with increasing sedimentation of organic matter $[9,14]$ (Figure 3).

On this basis, we used resuspension of soft superficial sediment with high organic load as an environmental management method for the western basin of Orbetello lagoon. During the process of resuspension, sedimentary organic matter artificially resuspended in the water column is mineralised, especially labile organic matter, the portion more readily attacked by bacteria, including sulphatereducing species. By reducing organic load, this process reduces the risk of dystrophy [13].

\section{Description of an environmental dystrophic event in Orbetello lagoon - July 2015}

The period between $7^{\text {th }}$ and $25^{\text {th }}$ July 2015 was characterised by a North African anticyclone that extended over most of the Mediterranean, especially the Tyrrhenian Sea. Water temperatures rose in response to a persistent mass of continental subtropical air that moved north from the African deserts (LaMMA, agency of the Tuscan Regional Administration and National Council of Research, pers. comm.). Surface water temperatures in the Tyrrhenian reached $29-30^{\circ} \mathrm{C}$ to a depth of $15 \mathrm{~m}$. In Orbetello lagoon, where sea water was being pumped in at 12 cubic metres per second at a temperature of $30^{\circ} \mathrm{C}$, water temperatures reached $34^{\circ} \mathrm{C}$ (ARPAT, Tuscan Regional Agency for Environmental Protection, pers. comm.). This was certainly a major stress for fish in the lagoon, and compounded with intense bacterial activity on the bottom. Measures undertaken by us at the time estimated labile organic matter in sediment of the eastern lagoon at $11.08 \pm 5.11 \%$ (range 5.97-16.20\%) and that in the western lagoon, subject to artificial resuspension of sediment, at $8.79 \pm 2.54 \%$ (range 5.15 $13.07 \%$ ). In July, patches of dystrophic activity in the eastern basin eventually led to about $70 \%$ of the surface being affected by reducing anoxic water, whereas in the western basin only a few marginal areas were affected. Most of the fauna died in the eastern lagoon: 129 tons of fish had to be removed (Municipal administration, pers. comm.).

\section{Estimates of microphytic bloom}

After the dystrophic event, the lagoon water became intensely coloured by detritus, colloidal sulphur, sulphur compounds and bacteria for about a month. This was followed by a bloom of microorganisms, including cyanobacteria which became dominant. This intense bloom lasted from September 2015 to mid January 2016. On $9^{\text {th }}$ November 2015 a sample obtained by mixing three samples taken in different areas was sent fresh to the Laboratory of Ecology and Plant Physiology in Florence. On $15^{\text {th }}$ December, three samples were fixed with Lugol and sent to the laboratories of the Tuscan Regional Agency for Environmental Protection (ARPAT). 
Figure 1. The Orbetello Lagoon, situated on the Tyrrhenian coast, with its western and eastern basins. Black ellipses are stations where organic matter was sampled in sediment. Black line in eastern basin separates sampling stations in the western (EL-W) and eastern (EL-E) halves of this basin. Green indicates the area affected by cyanobacterial bloom. X, fixed station for anemographic recording.

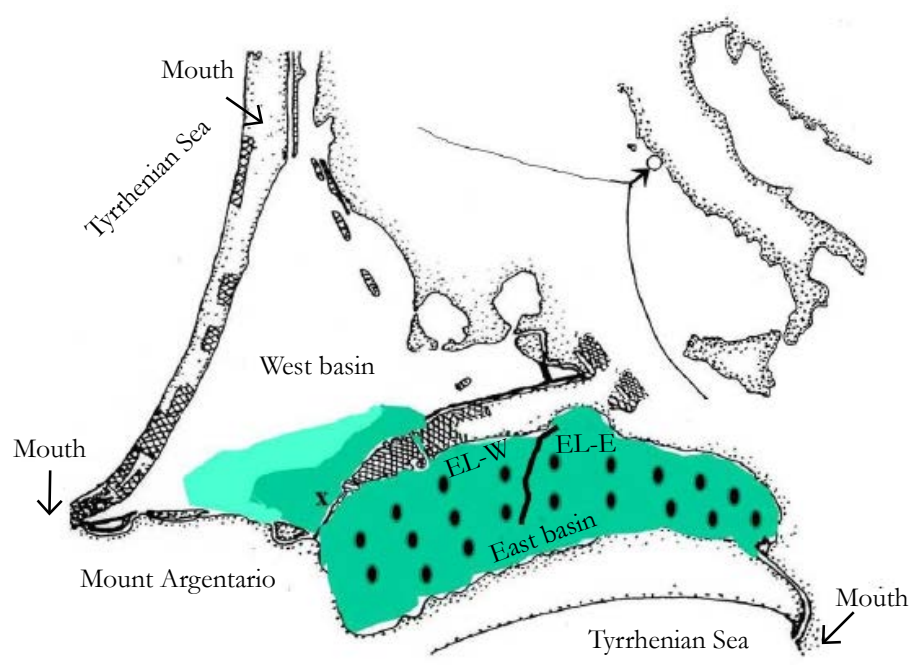

Figure 2. Principal variables, interaction of which can trigger an extensive dystrophic process. In red, the highest risk occurs when summer temperatures and sediment organic load are high while water movements are low. In orange, less risk occurs with high temperatures and high organic load but some water movement. The latter variable can prevent a dystrophic event if it is sufficiently high in relation to the other two variables.

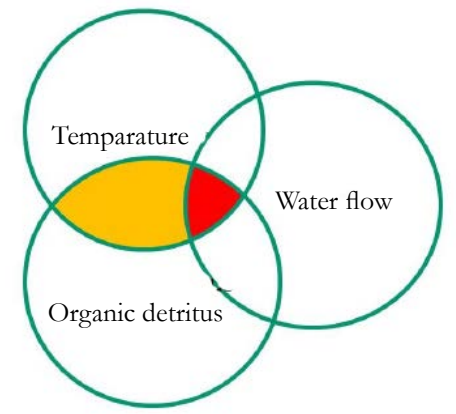

Figure 3. Conceptual model of eutrophication in shallow, non-tidal lagoons. As sediment organic matter (OM) gradually increases, the quality and quantity of aquatic vegetation changes (hpd, high plant diversity; R, Rhodophyta dominance; R-Ch, Rhodophyta and Chlorophyta miz; Ch, Chlorophyta dominance), culminating in collapse of the biocenosis due to energy dissipation by sulphate-reduction (dystrophy). After this, vegetation cycles and accumulation of OM in sediment resume. Downward arrows indicate sinking of organic detritus, upward arrows indicate nutrient release by sediment, and horizontal arrows indicate transition from sediment release of nitrogen prevalently as nitrates to prevalently as ammonium

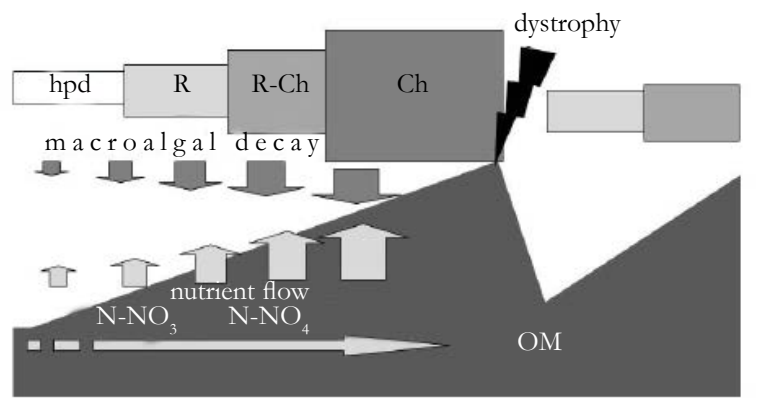


Figure 4. Prevalent direction and intensity of winds exceeding $8 \mathrm{~m} \mathrm{~s}^{-1}$ and areas of the eastern basin most exposed to the effects of wind (downward arrows indicate WN-westerlies; upward arrows indicate SE-easterlies). Small circles indicate sediment sampling stations for determination of organic matter. Sampling stations are divided by a line separating those in the western half (EL-W) of the basin from those in the eastern half (EL-E).

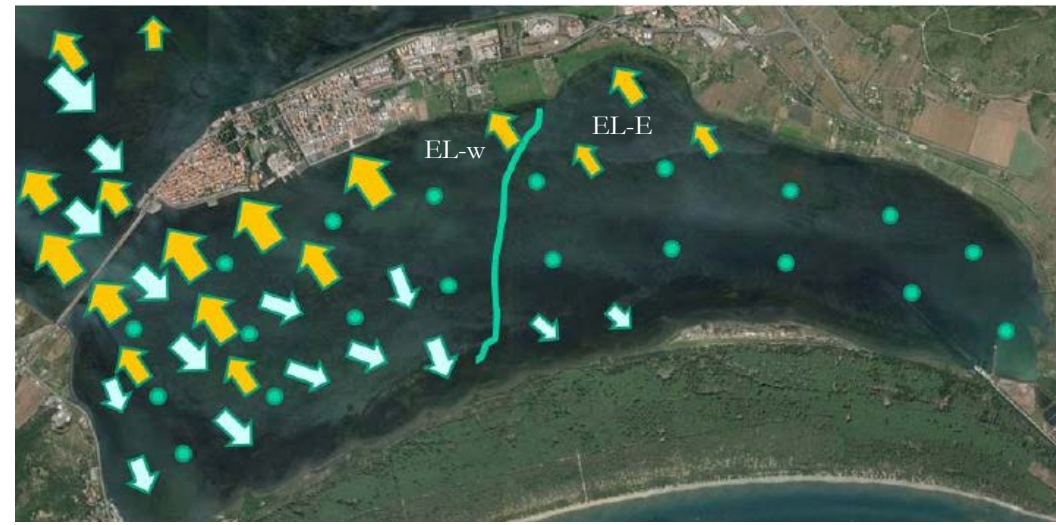

\section{Water temperature}

Water temperatures $\left(t,{ }^{\circ} \mathrm{C}\right)$ were obtained from two multiparametric stations managed by ARPAT. These record variables at intervals of 15 minutes and send them by radio to the agency where they are made available directly online (http://sira.arpat.toscana.it/ apex $2 / \mathrm{f}$ ? $\mathrm{p}=111: 2: 0:: \mathrm{NO}$ ) or processed on the ARPAT website (www.arpat.toscana.it/). The stations are located in the centres of the eastern and western basins of the lagoon.

\section{Estimates of wind speed and direction}

Wind is the only force that can significantly stir up the waters of Orbetello lagoon, which is non- tidal and laminar: tides and artificial pumping in of sea water do not cause sufficient movement. It has been estimated that wind speeds exceeding $8 \mathrm{~m}$ $\mathrm{s}^{-1}$ are sufficient to move soft superficial sediment layers, even in the deeper central parts of the lagoon [11].

We obtained wind direction and speed from the Tuscan Regional Meteorology and Hydrology Centre, which has an anemograph in Orbetello lagoon (Figure 1).

\section{Organic matter determination}

Twenty samples of sediment (upper $3 \mathrm{~cm}$ ) were collected in June, September and December 2015 and February 2016, along two longitudinal transects in the eastern basin (Figure 1), lowering an appropriately guided horizontal sampler with $60 \mathrm{~mL}$ syringe from the boat [17]. The samples were frozen until analysis. All samples were wet sieved with fresh water $\left(1 \mathrm{~mm}\right.$ mesh), dried at $75^{\circ} \mathrm{C}$ for
$48 \mathrm{~h}$ and weighed. Labile organic matter (LOM) was determined as loss of weight after combustion in a muffle furnace for $6 \mathrm{~h}$ at $250^{\circ} \mathrm{C}$. Refractory organic matter $(\mathrm{ROM})$ was estimated by weighing samples after further combustion for $6 \mathrm{~h}$ at $450^{\circ} \mathrm{C}$ [18]. On the basis of exposure to different prevailing winds, we also conducted the estimates dividing the sampling stations according to their location in two halves of the eastern basin: a western half $(\mathrm{EL}-\mathrm{W})$ and an eastern half (EL-E) (Figure 1).

\section{Statistic analysis}

LOM and ROM data was processed by two-way ANOVA to detect significant differences between the factors Month (DEC15 vs. FEB-15) and Basin (EL-W vs. EL-E). Cochran's C-test was used before each analysis to check for homogeneity of variance [19]. The Student Newman Keuls (SNK) test was used for a posteriori multiple comparison of means. All statistical tests were performed with Statistica version 10.0 software and the critical value in all tests was $P=0.05$.

\section{Results}

\section{Estimates of microphytic bloom}

The eastern basin experienced microphytic bloom from September 2015 until mid-January of the following year, presumably terminating when the temperature dropped. Driven by wind and modest tidal flow, intensely coloured water flowed westward from the eastern basin, involving about 300 ha of the western lagoon (Figure 1). Table 1 shows the dominant species of the microphytic bloom, microphytic density and concentrations

Table 1. Species and density, as number of cells, of the cyanobacteria bloom, and chlorophyll a (Chl a) and total chlorophyll (tot Chl), in the eastern basin of Orbetello lagoon, between September 2015 and January 2016.

\begin{tabular}{|c|c|c|}
\hline & $\min$ & $\max$ \\
\hline total cells & $245^{*} 10^{6}$ & $463^{*} 10^{6}$ \\
\hline Synechococcus group & $245^{*} 10^{6}$ & $463^{*} 10^{6}$ \\
\hline Chl a & & $31.36 \mathrm{mg} \mathrm{L}^{-1}$ \\
\hline tot Chl & & $31.56 \mathrm{mg} \mathrm{L}^{-1}$ \\
\hline
\end{tabular}


Table 2. Temperatures (minimum and maximum) in ${ }^{\circ} \mathrm{C}$ for several months in 2014, 2015 and 2016 when the events studied here occurred or by way of comparison.

\begin{tabular}{|c|c|c|c|}
\hline & $\mathbf{2 0 1 4}$ & $\mathbf{2 0 1 5}$ & $\mathbf{2 0 1 6}$ \\
\hline Jan & $7.9-13.3$ & $3.7-12.5$ & $5.5-14.5$ \\
\hline Feb & $11.1-14.9$ & $6.4-12.1$ & $10.7-15.7$ \\
\hline June & $23.3-28.9$ & $24.8-28.7$ & \\
\hline July & $25.4-28.3$ & $29.4-33.7$ & \\
\hline Aug & $25.6-29.5$ & $26.5-31.7$ & \\
\hline Sept & $22.2-26.7$ & $18.5-29.0$ & \\
\hline Oct & $15.3-23.8$ & $14.8-22.8$ & \\
\hline Nov & $15.3-18.5$ & $8.2-18.4$ & \\
\hline Dec & $4.0-17.5$ & $10.4-13.8$ & \\
\hline
\end{tabular}

of chlorophyll a and total chlorophyll. The latter exceeded $31 \mu \mathrm{g}$ $\mathrm{L}^{-1}$.

\section{Temperature}

Table 2 shows ranges of water temperature (minimum-maximum) during the nine months necessary for the study in the years 2014, 2015 and 2016.

\section{Estimates of wind speed and direction}

Between January and February and continuing into March, after the last estimates of LOM, there were many days of wind exceeding $8 \mathrm{~m} \mathrm{~s}^{-1}$. This wind speed is the threshold above which the affected area of this lagoon becomes subject to resuspension of sediment [11].

Table 3 shows the monthly frequencies of days with wind speeds $>8 \mathrm{~m} \mathrm{~s}^{-1}$, irrespective of wind duration, and the number of hours per month that such winds blew in this period. Between sampling in September and December (91 days), wind speeds above this threshold had a frequency of $16.32 \%$ and blew for a total of 122 h. Between the sampling of December and that of February (64 days), such winds had a frequency of $39.06 \%$ and blew for a total of $176 \mathrm{~h}$. In the latter period, south-westerlies and WN-westerlies had a frequency of $26.67 \%$, while SS-easterlies had a frequency of $46.66 \%$. Winds of such intensities stirred up very fine grey matter that remained in suspension in the water column for several days.

\section{Labile organic matter determination}

Table 4 shows mean ( \pm SD) values of LOM and ROM, calculated for all of the eastern basin in six trials between June 2014 and February 2016. Table 5 shows mean $( \pm S D)$ values of LOM and ROM for the two halves of the eastern basin: western half (ELW) and eastern half (EL-E).

For LOM, two-way ANOVA showed a significant effect of the interaction factor Month $\mathrm{x}$ Basin $(P=0.0012)$. The SNK post hoc test indicated that the values estimated in December in the two halves of the eastern lagoon were not significantly different $(P>0.05)$, unlike in February $(P<0.01)$. The post hoc test also showed that there were no significant temporal variations in $\mathrm{LOM}$ in the eastern half $(P>0.05)$, whereas the values recorded in the two months were significantly different in the western half $(P<$
0.01). Overall, the values recorded in December in the eastern basin $(20.59 \pm 12.55 \%)$ were significantly different from those recorded in February (12.54 $\pm 6.76 \%$ ).

Two-way ANOVA did not show any significant effects of the factor Month on ROM values $(P=0.970)$, whereas these values were significantly influenced by the factor Basin $(P=0.0009)$. The eastern and western halves of the eastern basin showed significantly higher values in the eastern half both in December and February.

\section{Discussion}

Labile organic matter (LOM) values, which were estimated to be greater in June 2014 than in June 2015 in the eastern basin $(16.11 \pm 9.49 \%$ e $11.8 \pm 5.11 \%$, respectively; Table 4$)$, did not produce dystrophy in July-August 2014, unlike in the same two months of 2015. This can be attributed to the higher temperatures reached in July 2015 (Table 2, Figure 2), in a context of low water movements for July, which were more pronounced in 2015. Indeed, in the first 20 days of July 2015, the period of the dystrophic event, wind speed only exceeded $4 \mathrm{~m} \mathrm{~s}^{-1}$ on two occasions, whereas in July 2014 there were two days with wind speeds of 6-7 $\mathrm{m} \mathrm{s}^{-1}$ and six days with wind speeds of 4-5 $\mathrm{m} \mathrm{s}^{-1}$ (Luca Angeli of the National Research Council, pers. comm.), while the flow of pumped sea-water was the same in the two periods.

After the dystrophic event, it seems likely that anoxygenic mineralisation of organic matter in sediment made large quantities of nutrients available, especially orthophosphates, as found under analogous circumstances in similar environments by Hijs et al. [16]. This would explain the massive bloom of cyanobacteria that began in September 2015 and continued until January 2016. As shown in Table 4, between September and December 2015, in a context of low winds $\left(16.32 \% \geq 8 \mathrm{~m} \mathrm{~s}^{-1}\right)$, sediments considerably increased their load of organic detritus. In the eastern basin there were no plant populations of phanerogams or macroalgae after the catastrophic summer dystrophy, so the only major source of organic detritus was the microphytic bloom itself (Table 1). This bloom reached high densities $\left(31.56 \mu \mathrm{g} \mathrm{L^{-1 }}\right.$ of $\left.\mathrm{Chl}\right)$, warranting classification of the basin as hypertrophic $\left(>20 \mu \mathrm{g} \mathrm{L}^{-1}\right.$ of Chl) on the chlorophyll-based scale of Håkanson et al. [20] for fresh, brackish and coastal marine waters. The rapid turnover of 
Table 3. Wind speed $>8 \mathrm{~m} \mathrm{~s}^{-1}$ as monthly frequency (f\%) and hours per month (h).

\begin{tabular}{|c|c|c|}
\hline & $\mathbf{f ~} \%$ & $\mathbf{h}$ \\
\hline 15-Jan & 25.80 & 100 \\
\hline 15-Feb & 21.43 & 31 \\
\hline 15-Sep & 16.67 & 70 \\
\hline 15-Oct & 25.81 & 50 \\
\hline 15-Nov & 13.33 & 28 \\
\hline 15-Dec & 0.00 & 0 \\
\hline 16-Jan & 35.48 & 83 \\
\hline 16-Feb & 65.52 & 145 \\
\hline
\end{tabular}

Table 4. Labile organic matter (LOM) and refractory organic matter (ROM) estimated in samples from the eastern basin of Orbetello Lagoon between July 2014 and February 2016.

\begin{tabular}{|c|c|c|}
\hline & LOM & ROM \\
\hline 14-Jul & $16.11 \pm 9.49$ & $9.29 \pm 1.14$ \\
\hline 14-Sep & $9.93 \pm 0.41$ & $10.02 \pm 0.85$ \\
\hline 15-Jun & $11.08 \pm 5.11$ & $8.65 \pm 0.74$ \\
\hline 15-Sep & $9.67 \pm 0.2$ & $10.76 \pm 0.18$ \\
\hline 15-Dec & $20.59 \pm 12.55$ & $9.12 \pm 1.43$ \\
\hline 16-Feb & $12.54 \pm 6.76$ & $9.25 \pm 1.61$ \\
\hline
\end{tabular}

Table 5. Labile organic matter (LOM) estimated in samples from the eastern basin (EL) of Orbetello lagoon in December 2015 and in February 2016, dividing the basin into two halves: western (EL-W) and eastern (EL-E).

\begin{tabular}{|c|c|c|c|c|}
\hline & LOM EL-W & LOM EL-E & ROM EL-W & ROM EL-E \\
\hline $15-\mathrm{Dec}$ & $25.57 \pm 15.55$ & $15.61 \pm 4.86$ & $8.28 \pm 1.27$ & $10.17 \pm 0.77$ \\
\hline $16-\mathrm{Feb}$ & $8.76 \pm 2.69$ & $16.4 \pm 6.43$ & $8.65 \pm 1.21$ & $9.84 \pm 1.73$ \\
\hline
\end{tabular}

cyanobacterial cells probably produced intense, prolonged fallout of dead cells, determining a $112.93 \%$ increase in sediment LOM between September and December. It is well documented that blooms of phytoplankton and bacteria can be the cause of major sedimentary deposition, sufficient to lead to striking dystrophic processes. For example, along the coasts of Namibia, the phenomenon has long been studied and documented by remote sensing [21, 22], and returning to lagoon environments, microphytic blooms have often been the cause of dystrophic events in the lagoon of Comacchio (Italy) [23].

The sampling period from December to February 2016 (64 days) was characterised by a very high frequency of strong winds $(39.06 \%)$, sufficient to resuspend sediments and cause their oxygenic mineralisation by the biogeochemical processes described in general terms in Lenzi [13]. Resuspension must occur with a relatively high frequency to reduce organic load, as found by Stahlberg et al. [24], and Lenzi and Renzi [17]. That this actually happened is confirmed by subsequent estimates of LOM on samples collect on $18^{\text {th }}$ February. These values were significantly lower, falling from $20.59 \pm 12.55 \%$ to $12.54 \pm 6.76 \%$ (Table 4). However, if we divide samples according to provenance from the eastern (EL-E) or western (EL-W) half of the eastern lagoon, and compare them with a similar division for the December samples (Table 5), we observe that the variations are localised in EL-W, where LOM fell by $65.74 \%$. By contrast, in the EL-E half
LOM remained substantially stable, increasing by $5.06 \%$. This is explained by the direction of the strong prevailing winds that mainly caused resuspension of sediment in the western half of the basin, as proposed in Figure 4.

ROM did not show variations after resuspension. This organic matter remains largely refractory even during transport in the water column and subsequent resedimentation together with oxygenic bacteria, as described by Logan and Kirchman [25]. ROM presumably arises from leaf detritus of the phanerogam Ruppia cirrhosa, which forms often very dense meadows along the sandy spit that divides the eastern basin from the sea (Figure 1). The meadows are more abundant and denser in the eastern half of the basin [26], and the leaves that periodically break off are mostly transported towards the mouth of the sea-lagoon canal, which explains the difference, stable in time, of the ROM contents in the two halves of the eastern lagoon.

Sediment resuspension is a phenomenon that can affect many environmental characteristics of non tidal lagoons [13] and in these environments, wind is the primary hydrodynamic factor [27]. It can cause resuspension of sediment and direct the development of benthic communities. On this question, Rubegni et al. [11] showed that in eutrophic water bodies, phanerogams are forced into shallower peripheral areas that are more subject to resuspension of sediment by wind, and this reduces organic load, 
whereas the consequences of eutrophication are more evident in deeper water, less subject to the action of wind, where organic matter accumulates. In the present study, we demonstrated that rare events like frequent strong winds can also reduce organic load in deeper parts of the lagoon.

\section{Conclusion}

Eutrophication and global warming are a combination that creates increasingly extreme conditions in shallow coastal lagoons with poor water exchange, raising the frequency of dystrophic processes, destructive of biocoenoses. They also lead to blooms of prevalently anaerobic bacteria.

Resuspension of soft superficial sediments proves capable of reducing the energy accumulating in eutrophic coastal ecosystems. In marine and lagoon environments, dissipation of organic matter occurs prevalently by an anoxygenic pathway [6], and it is therefore a rare event for dissipation to occur by an oxygenic pathway. In the present case study, it occurred partly due to strong winds (wind speeds $>8 \mathrm{~m} \mathrm{~s}^{-1}$ ). To our knowledge, the frequent series of strong winds in July 2015, that was sufficient to resuspend sedimentary detritus even in deeper parts of the lagoon, has no recorded precedent.

These results confirm that artificial resuspension of organicrich soft superficial sediment by means of appropriate devices can be an effective method for counteracting the sequelae of eutrophication, especially in the Mediterranean environment, where the warming trend can be critical.

\section{Acknowledgements}

We thank Dr. Caterina Nuccio and Dr. Chiara Melillo of the Ecology and Physiology Laboratory, Department of Biology of Florence University, and Dr. Gioia Benedettini of the Tuscany Regional Environmental Protection Agency, for the estimate and determination of cyanobacteria.

\section{References}

[1]. Smetacek V, Zingone A (2013) Green and golden seaweed tides on the rise. Nature 504(7478): 84-88.

[2]. Green P. A., Vörösmarty, C. J., Meybeck M., Galloway J. N., Peterson B. J., \& Boyer E. W (2004). Pre-industrial and contemporary fluxes of nitrogen through rivers: a global assessment based on typology. Biogeochemistry 68(1): 71-105

[3]. Leemans R, Eickhout B (2004) Another reason for concern: regional and global impacts on ecosystems for different levels of climate change. Global Environ Change 14(3): 219-228.

[4]. Anderson DM, Cembella AD, Hallegraeff GM (2012) Progress in understanding harmful algal blooms: paradigm shifts and new technologies for research, monitoring, and management. Ann Rev Mar Sci 4: 143-176

[5]. Morand P, Merceron M (2005) Macroalgal population and sustainability. J. Coast. Res 21(5): 1009-1020

[6]. Jørgensen B B (1983) The microbial sulphur cycle. In W. Krumbein (Ed.),
Microbial Geochemistry. Blackwell Scientific Publications, Oxford 91-124.

[7]. Lenzi M, Finoia MG, Persia E, Comandi S, Gargiulo V, et al. (2005) Biogeochemical effects of disturbance in shallow water sediment by macroalgae harvesting boats. Marine Pollution Bulletin 50 (5): 512-519.

[8]. Lenzi M, Birardi F, Calzolai R, Finoia M G, Marcone F, et al. (2010) Hypertrophic lagoon management by sediment disturbance. Marine Pollution Bulletin 61(4-6): 189-197.

[9]. Lenzi M, Renzi M, Nesti U, Gennaro P, Persia E, Porrello S (2011) Vegetation cyclic shift in eutrophic lagoon. Assessment of dystrophic risk indices based on standing crop evaluation. Estuarine, Coastal and Shelf Science.

[10]. Lenzi M, Finoia MG, Gennaro P, Mercatali I, Persia E, Solari J, et al. (2013) Assessment of resuspended matter and redistribution of macronutrient elements produced by boat disturbance in a eutrophic lagoon. J Environ Manage 123: 8-13.

[11]. Rubegni F, Franchi E, Lenzi M (2013) Relationship between wind and seagrass meadows in a non-tidal eutrophic lagoon studied by a wave exposure model (WEMo). Marine Pollution Bulletin 70(1-2): 54-63.

[12]. Martelloni T, Tomassetti P, Gennaro P, Persia E, Persiano M, Falchi R, Porrello $S$, Lenzi $M$ (submitted) Influence of sediment resuspension by boats on zoobenthic assemblages in a eutrophic lagoon. Marine Pollution Bulettin.

[13]. Lenzi M (2010) Resuspension of Sediment as Method for Managing Shallow Eutrophic Lagoon. Journal of Ecology and the Natural Environment 2 (11): 220-234.

[14]. Lenzi M, Gennaro P, Renzi M, Persia E, Porrello S (2012) Spread of Alsidium corallinum C. Ag. in a Tyrrhenian eutrophic lagoon dominated by opportunistic macroalgae. Marine Pollution Bulettin 64(12): 2699-2707.

[15]. Lenzi M, Palmieri R, Porrello S (2003) Restoration of the eutrophic Orbetello lagoon (Tyrrhenian Sea, Italy): water quality management. Marine Pollution Bulletin 46(12): 1540-1548.

[16]. Hijs S K, Azzoni R, Giordani G, Jonkers H M, Zizzoli D, et al. (2000) Sulphide-induced release of phosphate from sediments of coastal lagoons and the possible relation to the disappearance of Ruppia sp. Aquat. Microb. Ecol 23(1): 85-95.

[17]. Lenzi M, Renzi M (2011) Effects of artificial disturbance on quantity and biochemical composition of organic matter in sediments of a coastal lagoon. Knowl. Manag. Aquat. Ecosyst 402 (08).

[18]. Loh PS (2005) An assessment of the contribution of terrestrial organic matter to total organic matter in sediments in Scottish sea lochs, Ph.D. thesis, UHI Millenium Institute, 350 .

[19]. Underwood AJ (1997) Experiments in ecology. Their logical design and interpretation using analysis of variance. Cambridge University Press, Cambridge 12(10): 410-411.

[20]. Håkanson L, Bryhn A C, Blenckner T (2007) Operational Effect Variables and Functional Ecosystem Classifications. A review on empirical models for aquatic systems along a salinity gradient. International Review of Hydrobiology 929(3): 326-357.

[21]. Emeis K C, Brüchert V, Currie B, Endler R, Ferdelman F, et al. (2004) Shallow gas in shelf sediments of the Namibian coastal upwelling ecosystem. Cont. Shelf Res 24(6): 627-642.

[22]. Ohde T, Siegel H, Reixmann J, Gerth M (2007) Identification and investigation of sulphur plumes along the Namibian coast using the MERIS sensor. Continental Shelf Research 27(6): 744-756.

[23]. Sorokin Yu I, Sorokin P Yu, Gnes A (1996) Structure and functioning of the anthropogenically transformed Comacchio lagoonal ecosystem (Ferrara, Italy). Mar. Ecol. Prog. Ser 33(1-3): 57-71.

[24]. Stahlberg C, Bastviken D, Svensson BH, Rahm L (2006) Mineralisation of organic matter in coastal sediment at different frequency and duration of resuspension. Estuar. Coast. Shelf Sci 70(1-2): 317-325.

[25]. Logan BE, Kirchman DL (1991) Uptake of dissolved organics by main bacteria as a function of fluid motion. Marine Biology 111(1): 175-181.

[26]. Giovani A, Mari E, Specchiulli A, Cilenti L, Scirocco T, et al. (2010) Factoris affecting changes in phanerogams distribution patterns of Orbetello lagoon, Italy. Transitional Water Bulletin 4 (1): 35-52.

[27]. Brambati A (1988) Lagoons and coastal ponds: a comparison of two environments. In: Le lagune costiere: ricerca e gestione Istituto di Geologia e Paleontologia Eds., U. d. T.: 9-33 